Prace Historyczno-Archiwalne t. XXXIII, Rzeszów 2021

ISSN: 1231-3335

\title{
Kathryn Ciancia, On Civilization's Edge. A Polish Borderland in the Interwar World, Oxford University Press, New York 2021, ss. XIV + 343
}

1

imothy Snyder zapoczątkował wśród historyków anglosaskich nurt badań zwrócony ku dziejom pogranicza państwowego, etnicznego i cywilizacyjnego w Europie Wschodniej. Recenzowana książka doskonale się w tę tendencję wpisuje. Poszerza stan wiedzy o historii województwa wołyńskiego w okresie międzywojennym dzięki wprawnemu użyciu nowych metod badawczych i oparciu o szeroką podstawę źródłową. Prócz tej inspiracji ważną rolę odegrały więzi rodzinne autorki z Polską poprzez jej dziadka, Adolfa Stępnia, urodzonego w 1913 r. w zaborze rosyjskim, oficera Wojska Polskiego, który po kampanii wrześniowej wyemigrował do Wielkiej Brytanii. Dość wspomnieć, że Kathryn Ciancia jest profesorem uczelni w stanowym Uniwersytecie Wisconsin-Madison, który ma najdłuższą tradycję nauczania o historii, kulturze i języku polskim w USA.

Szeroki dobór metod badawczych, użytych do tworzenia analitycznych opisów i syntetycznych uogólnień, ma jedno wspólne odniesienie w postmodernistycznym paradygmacie humanistyki. Autorka wykorzystała teorie postkolonialne i postnacjonalistyczne z elementami tzw. case studies, widocznymi w każdej partii pracy. Skupiła się na przedstawieniu historii ludzi poddawanych cywilizowaniu, czyli znajdujących się w pozycji przedmiotu dziejów. Często powoływała się na źródła wytworzone przez „aktorów drugoplanowych” w historii międzywojennego województwa wołyńskiego, będących narzędziem władzy w planach cywilizowania tego obszaru: nauczycieli, lekarzy, osadników wojskowych i strażników granicznych, harcerzy, działaczek kobiecych. Nowatorskim wydaje się zwrot ku feminizmowi. W kwestionariuszu badawczym autorki znalazły się także pytania o losy dzieci.

Odnieść można wrażenie, że autorka chciała też odnaleźć sprawczość przyrody nieożywionej w dziejach Wołynia, przez co jej książka metodologicznie sięga do posthumanistyki. Wskazują na to fragmenty opisu miejsca i roli bagien poleskich w polityce modernizacyjnej Wołynia oraz krajobrazu tego obszaru w polityce turystycznej międzywojennej Polski. Recenzowana praca należy ze wszech miar do nurtu badań regionalnych. Jej zakończenie, w którym znalazły się nawiązania do aktualnych dyskusji i polityki historycznej w Polsce, pokazuje, że autorka hołduje etosowi historyka zaangażowanego (widać inspiracje Haydenem Whitem) i chciałaby, jak przypuszczam, by jej praca stała się też głosem w owych dyskusjach, a być może wpłynęła na poprawienie jakości owej polityki historycznej.

Autorka zaprezentowała wysoki poziom erudycji; imponuje jej świetna orientacja w literaturze polskojęzycznej. Zdumiewa jednak, że pominęła opracowania Zbigniewa Zaporowskiego o ukraińskich posłach i senatorach z Wołynia i Marcina Łukasza Majewskiego o polityce Henryka Józewskiego wobec zjawiska ukraińskie- 
go terroryzmu nacjonalistycznego i komunistycznego ${ }^{1}$. Obecność reprezentacji ludności ukraińskiej z województwa wołyńskiego w polskim parlamencie w okresie międzywojennym można przecież było zanalizować w kierunku podjętego przez autorkę tematu cywilizowania pogranicza. Książka została solidnie podparta źródłami archiwalnymi aż z 14 placówek archiwalnych i bibliotecznych w: Polsce, USA, Wielkiej Brytanii i na Ukrainie. Szeroki jest ponadto zakres kwerendy czasopiśmienniczej, który objął 50 periodyków: polsko-, ukraińsko-, francusko- i anglojęzycznych, wydawanych w okresie międzywojennym.

Publikacja została podzielona na siedem rozdziałów, które poprzedza wstęp, a wieńczy zakończenie. Uzupełniają ją skumulowane na jej końcu przypisy, wykaz wykorzystanych źródeł i opracowań oraz jeden indeks - jednocześnie tematyczny, dla nazwisk i miejsc geograficznych. Licznie zdobią książkę ilustracje, opatrzone trafnymi komentarzami, oraz mapy. Równe pod względem objętości rozdziały dobrze się komponują. Każdy z nich stanowi odrębne studium, jak również jest wprowadzeniem do kolejnego rozdziału.

Autorka rozpoczęła I rozdział, zatytułowany Democracy as Civilizing Mission, od rozważania, czy „Czternaście punktów Wilsona” rzeczywiście dawało Polsce prawo do władania nad Wołyniem. Zanalizowała polskie broszury propagandowe, powstałe w czasie obrad konferencji pokojowej w Paryżu, w których przekonywano zachodnią opinię publiczną co do słuszności polskich pretensji do tego obszaru. Polska, jak uzasadniała jej dyplomacja, była predestynowana do jego ucywilizowania i zdemokratyzowania. Argumentacja ta miała nielicznych zwolenników na Zachodzie; autorka wymieniła historyka angielskiego Harolda Temperleya, natomiast więcej przeciwników: Jana Smutsa, George'a Louisa Beera, Davida Lloyda George'a. Następnie skierowała uwagę na tak istotną w kontekście cywilizowania Wołynia okoliczność, że nie odbyły się tam wybory do Sejmu Ustawodawczego w 1919 r. Na demokratyzowanie tego regionu było jeszcze za wcześnie, z uwagi na fakt braku stabilizacji politycznej, prawnej i wojskowej. Co więcej, polski reżim okupacyjny umocnił się po owych wyborach, gdy utworzony został Zarząd Cywilny Ziem Wschodnich, a następnie Zarząd Cywilny Ziem Wołynia i Frontu Podolskiego. W ramach tej analizy omówiona została działalność Straży Kresowej, jej wydawnictw, redagowanych m.in. przez Melchiora Wańkowicza (np. „Polak Kresowy”), poglądów wybranych instruktorów tej organizacji, przybyłych - co podkreśliła autorka - ze stolicy Polski, a więc spoza Wołynia. Autorka pokazała, że Straż Kresowa przeciwstawiała demokrację imperializmowi. Środkiem perswazji było kojarzenie demokracji z Polską i polskości z cywilizacją zachodnią, a imperializmu z Rosją (wówczas już nie carską, a radziecką). Stosunek tej organizacji do wołyńskich Żydów cechował się ambiwalencją, a do wiejskiej ludności ruskiej - protekcjonalnością i paternalizmem.

W rozdziale II, zatytułowanym The Integration Myth, autorka ukazała województwo wołyńskie jako peryferium Polski, którego nowa administracja państwowa nie potrafiła unowocześnić. Przedstawiła związane z tym utyskiwania polityków polskich. Ciężar zainteresowania autorki wzięli na siebie w przeważającej mierze endecy (np. Joachim Bartoszewicz, Stanisław Grabski, Jan Zamorski, Jan Biliński itd.)

1 Z. Zaporowski, Wołyńskie Zjednoczenie Ukraińskie. Wołyńske Ukrainśke Obiednannia, Lublin 2000; M.Ł. Majewski, Wołyń. Komunizm, nacjonalizm, terroryzm. Wojewoda wołyński wobec ukraińskich organizacji terrorystycznych na Wołyniu 1928-1938, Warszawa 2014. 
i ich wydawnictwa prasowe (np. „Myśl Narodowa”, „Gazeta Warszawska”, „Życie Wołynia”, „Kurier Poznański”). Autorka uwydatniła fakt zacofania społecznego tej części Polski, na co składały się: wysoki wskaźnik niepiśmienności (drugi pod względem wielkości w Polsce, co zostało wyraźnie podkreślone), stojąca na niskim poziomie kultura rolna, również niski - w skali kraju - wskaźnik urbanizacji i rzadka sieć kolejowa o nadzwyczaj niepraktycznej konfiguracji stacji. Stan ten był skutkiem przeszłości kolonialnej Wołynia. Rezultat wyborów do I kadencji izb ustawodawczych w 1922 r. na obszarze województwa wołyńskiego jest dla autorki potwierdzeniem, że owa integracja była niespełnionym marzeniem polskich zwolenników polonizacji tego regionu. Nie przeszkadzało to Polakom w utożsamianiu tam polskości ze swojskością i jednoczesnym dopatrywaniu się obcości w miejscowych Żydach. Znamienne, że pracujący w województwie wołyńskim urzędnicy polscy z byłej już wtedy Galicji również traktowani byli jako obcy, w czym szczególną rolę odegrały elity polityczne z Wielkopolski. Autorka zanalizowała następnie formację Korpusu Ochrony Pogranicza. Jej żołnierze mieli spełniać rolę cywilizatora, jednak wywoływali nieufność, a czasem nawet wrogość u autochtonicznej ludności.

Rozdział III pt. The Many Meanings of the Border rozpoczyna się od opisania napięcia na granicy polsko-radzieckiej po zawarciu traktatu ryskiego. Jan Jacek Bruski trafnie porównał je do „zimnowojennej” atmosfery² ${ }^{2}$ Autorka zanalizowała w nim zjawiska (re)emigracji, głównie ludności żydowskiej i tzw. bieżeńców, do Polski tuż po zakończeniu wojny polsko-radzieckiej w 1920 r. i nielegalnego przemytu przez granicę polsko-radziecką. Wartym uwagi wydaje się wniosek, że nielegalne przekraczanie granicy wynikało w głównej mierze z przyczyn ekonomicznych i potrzeb utrzymania więzów rodzinnych, które rozdarła nowa granica, niż politycznych czy szpiegowskich. Autorka wróciła w tej części pracy do analizy obecności KOP-u w województwie wołyńskim. Funkcją tej formacji było, prócz oczywistej ochrony granicy z ZSRR, udowodnienie stałości owej granicy, nierzadko agresywnie kwestionowanej na arenie międzynarodowej przez niejedną dyplomację państwową, m.in. radziecką.

Rozdział IV, zatytułowany Polish Towns? Jewish Towns?, zaczyna się od przedstawienia fatalnego stanu sanitarnego i budowlanego wołyńskich miast i miasteczek, będącego dziedzictwem kolonialnego zaniedbania tego obszaru przed 1914 rokiem i zniszczeń wojennych z lat 1914-1920. Zarówno Żydzi, jak i Polacy - jak wykazała autorka - wyrażali nieodpartą potrzebę ich przebudowy. Prawicowi politycy polscy chcieli jednak modernizować je bez udziału Żydów. To samo dotyczyło także Henryka Józewskiego, który planował wprawdzie radykalnie podnieść poziom życia w administrowanym przez siebie regionie, opierając się jednak na ekspertach spoza Wołynia i ignorując zdanie żydowskiej większości (jeśli chodzi o ośrodki miejskie). Na przykładzie działań starosty dubieńskiego Adama Kańskiego autorka omówiła działania obozu sanacyjnego w kierunku polonizowania tamtejszej przestrzeni urbanistycznej. Dochodziło wtedy do pewnego rodzaju starcia cywilizacyjnego między polskością, reprezentującą okcydentalizm tudzież europejskość, a żydowskością tych miast i miasteczek, będącą, w oczach polskich urzędników, emblematem nieucywilizowanego Wschodu.

2 J.J. Bruski, Między prometeizmem a Realpolitik. II Rzeczpospolita wobec Ukrainy Sowieckiej 1921-1926, Kraków 2010, s. 9. Autorka wykorzystała tę pracę w tłumaczeniu na język angielski (Kraków 2017). 
W rozdziale V - Depoliticizing the Volhynian Village - autorka uwypukliła to, co ustaliła w poprzednich rozdziałach, a mianowicie, że plany cywilizowania Wołynia powstawały wbrew wieloetnicznemu charakterowi tego obszaru. Polonizacja była w tym wypadku synonimem nowoczesności, lecz wyłącznie teoretycznie, bowiem w praktyce wprowadzana była nieudolnie. Autorka przedstawiła obraz zacofania prowincji wołyńskiej. Omówiła nieudaną realizację reformy rolnej, akceptację władzy dla istnienia serwitutów i zmuszanie chłopstwa do wykonywania szarwarków podczas osuszania terenów wokół prawych dopływów Prypeci. Wskazała następnie na fakt dezorganizacji społecznej na wsi wołyńskiej, która przejawiała się wzrostem zainteresowania sektami wyznaniowymi, nielegalnej działalności komunistów i nacjonalistów ukraińskich, a także nawoływaniem młodzieży polskiej przez dwóch księży katolickich do obywatelskiego nieposłuszeństwa.

W rozdziale VI pt. Regionalism, or the Limits of Inclusion autorka zanalizowała przyczyny reorientacji władzy ku kreowaniu odmienności regionalnej Wołynia od reszty Polski. Baczną uwagę zwróciła na założenie Muzeum Wołyńskiego w stolicy województwa. Wyraziła chwytliwą konkluzję, że jego eksponaty tworzyły „[p]rojekt wołyński nowoczesnym w formie, a przednowoczesnym w treści” (s. 170). Scharakteryzowała dalej działalność edukacyjną przewodniczącego Związku Nauczycielstwa Polskiego - Oddział na Wołyniu, Jakuba Hoffmanna, badania regionalne demografa Wiktora Ormickiego i badania terenowe Iwana Ziłyńskiego nad językiem chłopstwa ukraińskiego. W stosunku do Żydów wołyńskich polityka regionalna nadmiernie uwydatniała tolerancyjność Polski. Charakterystyczne było, że nie zwracano uwagi na funkcję religijną żydowskich obiektów sakralnych i ich znaczenie dla żydowskiej tożsamości, zachwycano się natomiast samym pięknem ich detali architektonicznych. Przesadnym zainteresowaniem - jak zauważyła autorka - otoczono łuckich Karaimów. Czyniono tak, co pośrednio wynika z jej konkluzji, by niejako przyćmić znaczenie wpływu miejscowych Żydów na rozwój regionalnej tożsamości. Autorka przytoczyła też jedno z często pojawiających się oskarżeń polityków Ukraińskiego Zjednoczenia Narodowo-Demokratycznego - że polityka regionalna w stosunku do Wołynia umotywowana była chęcią zdecentralizowania narodu ukraińskiego na poszczególne grupy etniczne.

Ostatni rozdział - Thinking Technocratically - rozpoczyna się od omówienia zmian w polskiej polityce w stosunku do mniejszości narodowych w drugiej połowie lat 30. XX w. Autorka zwróciła szczególną uwagę na to, że zjawisko retoryki politycznej uległo wtedy znaczącemu zaostrzeniu. Wyraziła interesujący osąd, że odgrywający rolę „drugoplanowych aktorów” w misji cywilizowania Wołynia regionaliści i badacze polscy (Józef Obrębski, Stanisław Dworakowski, Walenty Miklaszewski, Wiktor Ormicki, Edward Maliszewski) byli swego rodzaju marionetkami w rękach władzy. Ich działalność była szkodliwa dla lokalnej różnorodności etnicznej. Zależność ta była typowa dla innych, autokratycznych i totalitarnych, państw w owym czasie. W ramach rozważań nad technokratycznym podejściem władz do województwa wołyńskiego autorka zanalizowała aktywność Instytutu Badań Spraw Narodowościowych, Komisji Naukowych Badań Ziem Wschodnich, Towarzystwa Rozwoju Ziem Wschodnich. Zauważyła, że demografowie i geografowie polscy reagowali na spadek liczby ludności polskiej i jednoczesny wzrost ludności ukraińskiej w tej część Polski wypowiedziami o podtekście rasistowskim. Na tym tle umieściła ona 
m.in. zdanie wojewody poleskiego Stanisława Downarowicza o potrzebie zasiedlenia przez Polaków swego rodzaju „korytarza”, oddzielającego zamieszkiwane przez chłopstwo białoruskie Polesie od Wołynia. Następnie zwróciła uwagę na nurtujący polskich etnografów i geografów problem istnienia rozgraniczenia etnicznego polesko-wołyńskiego, które równoleżnikowo dzieliło na dwie części województwo wołyńskie. Zagadnienie to skupiało w sobie jak w soczewce dylematy cywilizacyjne, modernizacyjne i antropologiczne, przy czym ten ostatni był nacechowany ideologią rasową. Zabiegami mającymi na celu zwiększenie liczebne Polaków na tym obszarze były także: repolonizacja przedstawicieli dawnej, spauperyzowanej, zdegradowanej społecznie i wyznającej prawosławie szlachty tzw. zaściankowej, tzw. rewindykacja cerkwi prawosławnych, czyli uczynienie z nich na powrót świątyń katolickich, siłowe (przy użyciu KOP-u) zmuszanie do konwersji prawosławnych mieszkańców Hryniek, Lidawki, Hłuboczka na katolicyzm w 1938 r.

Książka Kathryn Ciancia pokazuje, jak rozumiano w okresie międzywojennym cywilizowanie zacofanych regionów w odrodzonym państwie polskim. Dla Polaków punktem odniesienia był zawsze Zachód. Ucywilizowanie Wołynia, będące - wedle ambitnie zakrojonego zamierzenia - jego okcydentalizacją, było niezmiernie trudne do wykonania. Według amerykańskiej badaczki, polska misja cywilizacyjna była wykonywana nieporadnie i okazała się przedsięwzięciem nieudanym, stanowiąc mierne naśladownictwo podobnych praktyk cywilizacyjnych np. w koloniach francuskich i brytyjskich. Zamierzeniem autorki było - jak sądzę - aby jej praca spełniła funkcję oczyszczającą wiedzę o Polsce w okresie międzywojennym ze „wzniosłej retoryki” (s. 73), „podwójnej mitologii obrony i ekspansji” (s. 74). Pomijając jednak to, czy polska kultura historyczna rzeczywiście potrzebuje swoistego katharsis, uważam, że recenzowana książka wzbogacić ją może o nowatorskie, pod względem metodologicznym, spojrzenie na Wołyń w okresie międzywojennym i stać się odniesieniem warsztatowym w badaniach nad innymi regionami pogranicza w Europie (Środkowo-JWschodniej.

Rafał Kolano

ORCID 0000-0002-7962-5403

DOI:10.30657/pha.33.2021.21

(historyk, Rzeszów)

e-mail: rflkolano20@gmail.com 